\title{
THE TRADITIONAL HOUSES CHARACTERISTICS LINKAGE AMONG ROKAN AND LUHAK AGAM
}

\author{
Muhammar Khamdevi*1 \\ Universitas Matana ${ }^{1}$ \\ E-mail: 1 m.khamdevi@gmail.com
}

\begin{abstract}
Abstrak_ Rumah Luhak Agam (termasuk Pasaman) di Sumatera Barat memiliki ciri khas tersendiri yang membedakannya dengan Rumah Gadang Minangkabau lainnya di Luhak Tanah Datar dan Luhak Limapuluh Koto. Lokasi Luhak Agam sangat dekat dengan kawasan Rokan di Riau. Sepintas, rumah adat mereka terlihat mirip, terutama pada bentuk atapnya. Oleh karena itu, penelitian ini mencoba untuk mengeksplorasi dan membandingkan karakteristik arsitektur mereka. Bagaimanakah keterkaitan karakteristik rumah-rumah mereka? Metode penelitian ini adalah kualitatif untuk melakukan perbandingan dan menggunakan sumber-sumber sejarah dan linguistik untuk mendapatkan kesimpulan yang lebih komprehensif. Sehingga penelitian ini dapat menunjukkan keterkaitan antara keduanya. Hasil penelitian menunjukkan bahwa terdapat proses asimilasi pada karakteristik rumah mereka yang menunjukkan adanya sharing budaya.
\end{abstract}

Kata kunci : Karakteristik Arsitektur; Rumah Tradisional; Rumah Gadang, Rumah Godang; Minangkabau-Melayu.

\begin{abstract}
Abstrak_ The Luhak Agam house (including Pasaman) in West Sumatra has its own characteristics that distinguish it from other Minangkabau's Rumah Gadang in Luhak Tanah Datar and Luhak Limapuluh Koto. The location of Luhak Agam is very close to the Rokan area in Riau. At a glance, their traditional houses look similar, especially in the shape of the roof. Therefore, this research tries to explore and compare their architectural characteristics. How is the linkage of the characteristics of their house? This research method is qualitative to make comparisons and use historical and linguistic sources to get a more comprehensive conclusion. So this research can show the linkage between them. The results showed that there is a process of assimilation in the characteristics of their houses which shows the existence of cultural sharing.
\end{abstract}

Keywords: Architectural Characteristics; Traditional House; Rumah Gadang; Rumah Godang, MinangkabauMelayu. 


\section{INTRODUCTION}

In the south of the area flows the Rokan River, where in the upstream there is the Luhak Agam (Agam-Pasaman) area and in the downstream there is the Rokan area. People in Rokan and people in Agam-Pasaman are now considered to be different ethnicities; Malay and Minangkabau. Even from linguistics, Minangkabau is still a Malayic speaker. By the Dutch, Minangkabau was separated and distinguished from Malay because it followed a matrilineal kinship system. Whereas Rokan, Kampar, and Kuantan also have the same system. Even in historical facts, the Rokan, Kampar, and Kuantan areas were the territory of the Paguruyung Kingdom, before being seized by the Johor-Riau Sultanate.

Table 1. Numbers in Minangkabau and Rokan Languages

\begin{tabular}{ccc}
\hline English & Minangkabau & Rokan \\
\hline One & $\begin{array}{c}\text { Ciek } \\
\text { Aso (Old) }\end{array}$ & $\begin{array}{c}\text { Ciek/ Satu } \\
\text { Oso (Old) }\end{array}$ \\
\hline Two & Duo & Duo \\
\hline Three & $\begin{array}{c}\text { Tigo (krama, from } \\
\text { "tika" in prakrit) } \\
\text { Telu (Old) }\end{array}$ & $\begin{array}{c}\text { Tigo (krama) } \\
\text { Telu (Old) }\end{array}$ \\
\hline Four & (A-)mpek & (O-)mpek \\
\hline Five & Limo & Limo \\
\hline Six & (A-)nam & (O-)nam \\
\hline Seven & Tujuah & Tujuah \\
\hline Eight & (Sa-)lapan & (Sa-)Lapan \\
\hline Nine & Sambilan & Sambilan \\
\hline Ten & Sapuluah & Sapuluah \\
\hline
\end{tabular}

Source: Khamdevi, 2017-2020

Kozok (2006) expressed that, based on the inscription of Lubuk Layang, the Malayapura Kingdom (Pre-Pagaruyung) set up a subordinate kingdom within the Pasaman - Mandailing Rokan area governed by a vice king named Bijayendrawarman. Tome Pires (2016) recorded that Rokan was ruled by a Chinese person under the leadership of the Sultanate of Malacca in 1,512 1,515 AD. After the Malacca Sultanate was crushed by the Portuguese, the Rokan became part of the Pagaruyung Sultanate. Soon after that, Rokan was seized by the Johor-Riau Sultanate, but still had the strong influence of the Pagaruyung Kingdom (Amran, 1981 and Navis, 1984). Linguistically, Rokan and Minangkabau are very close related, see Table 1. Both belong to the Malayic sublanguages of Austronesian that are specifically related to the languages of Greater North Borneo, where these languages started from Formosa through the Philippines to Borneo (Nothofer, 1985 and Anderbeck, 2007).

In the description above it is clear that these two regions share the same history and culture. But the problems that occur now are both considered to be different ethnicities; Minangkabau and Malay. And this caused a lot of identity tension between these two areas. This research is very important to show the relationship between the two areas, which until now are still considered to be different ethnicities. It is hoped that this research will also describe the relationship between the Hulu-Hilir-Pesisir (Upstream-Downstream-Coastal) regions. From the results of previous studies, it was found that there is a linkage of the architectural characteristics of traditional houses in Kampar with houses in Luhak Limopuluh Koto, both of which are connected by the Batang Kampar main river (Khamdevi, 2019b and Khamdevi, 2020a). Likewise, the houses in Kuantan 
have a characteristic architectural linkage with the houses in Luhak Tanah Datar, both of which are connected by the Batang Kuantan-Ombilin main river (Khamdevi, 2019a and Khamdevi, 2020b). What about Rokan and Luhak Agam which are connected by the Batang Rokan main river? At a glance the Rumah Gadang in Agam and the Rumah Godang in Rokan have similarities, see Figure 1. How is the linkage of both houses characteristics?
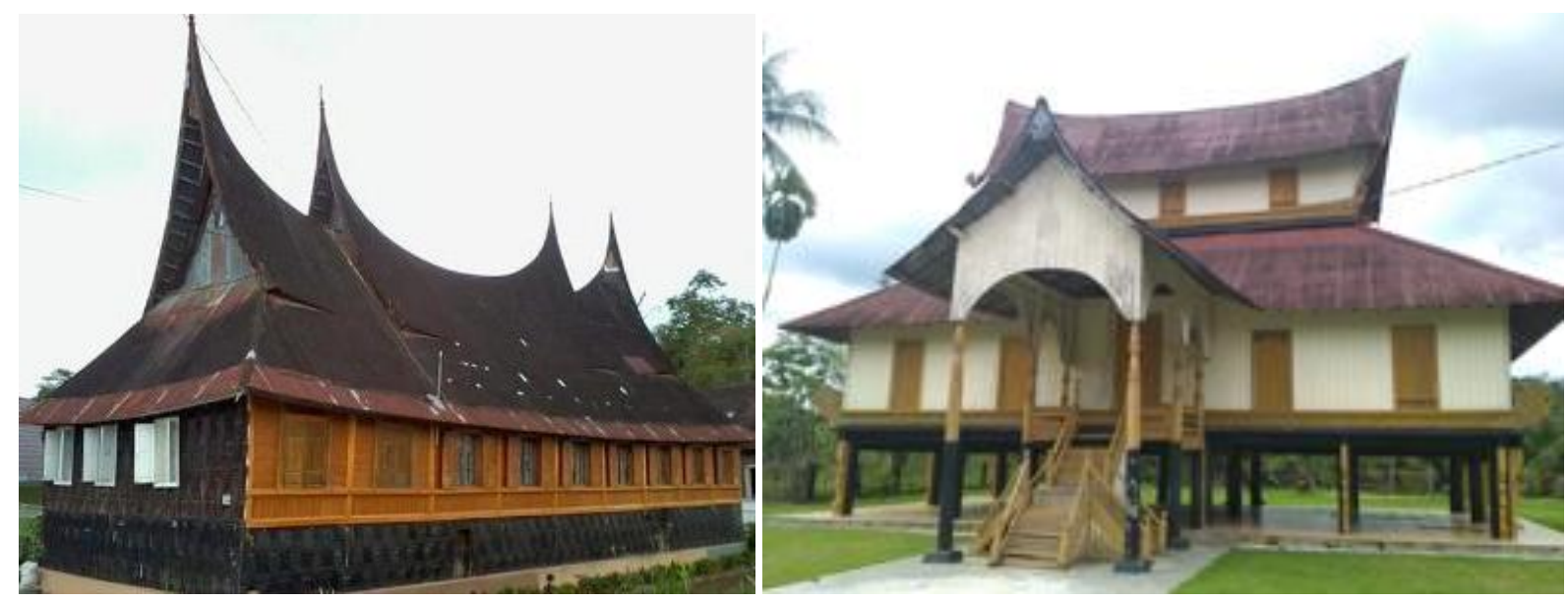

Figure 1. Rumah Gadang in Luhak Agam (left) and Rumah Godang in Rokan (right) Source: Khamdevi, 2017-2020

\section{RESEARCH METHOD}

This study is a qualitative research that conducted in the field. Habraken (1988) said that building characteristics can be analyze with three syatems, to be spesific: Spatial, Physical and Figural Configuration, and Stylistic. In line with that, Gero and Ding (2001) explained that the characteristics of the design consist of genotype (space), phenotype (shape-form), and style. Guney (2007) also stated that the typology in architectural discourse consists of genotype (spatial arrangement) and phenotype (the realization of the genotype). Basically these theories have the same discussion relationship. So it can be concluded that there are at least three main domains in analyzing architectural characteristics: space, form-shape, and style.

Table 2. The Architectural Characteristics of Rumah Gadang in Luhak Agam (Boestami et al., 1979; Syamsidar, 1991; Couto, 2008; and Schefold, 2008))

\begin{tabular}{llll}
\hline Traditional House & Architectural Characteristics & \\
\hline Rumah Gadang & $\begin{array}{l}\text { Space Pattern } \\
\text { Orientation } \\
\text { Hgam }\end{array}$ & $\begin{array}{l}\text { Balai }>\text { Labuh }>\text { Bandua }>\text { Bilik } \\
\text { River or Qibla } \\
\text { Public }>\text { Semi Public }>\text { Semi Privat }> \\
\text { Privat }\end{array}$ \\
& Physical form & $\begin{array}{l}\text { Gable and Hip Roof Combination } \\
\text { With curved ridge } \\
\text { Wood, Bamboo (Sasak), and Palm }\end{array}$ & $\begin{array}{l}\text { Materials } \\
\text { Fiber Roof } \\
\text { Wood Wall at Sleeping Room, } \\
\text { Tingkok/ Bandua, Papan Bandul }\end{array}$ \\
\hline
\end{tabular}




$\begin{array}{ll}\text { Roof } & \begin{array}{l}\text { Surambi Papek or Bapaserek, Lipek } \\ \text { Pandan, Boat (Lanchara/ } \\ \text { Lancang),Buffalo Horn, Gonjong } \\ \text { 1 Main Pole, Hexagonal or Octagonal } \\ \text { Cross Section }\end{array} \\ \text { Column } & \begin{array}{l}\text { Hinged Doors and Windows } \\ \text { Odd Number Steps (7-11 Steps) } \\ \text { Openings } \\ \text { Stairs } \\ \text { Ornaments } \\ \end{array} \\ & \begin{array}{l}\text { Fauna abstract shape \& Floral } \\ \text { (kaluak paku, itiak pulang patang, } \\ \text { pucuak rabuang, etc.) }\end{array} \\ \end{array}$

Source: Boestami et al., 1979; Syamsidar, 1991; Couto, 2008; and Schefold, 2008

A traditional house, as an artifact, portrayed the setting of culture and the social pattern and the way of life in a certain period of time. All of that can be made by the community itself, appropriated, acquired by past eras, or impacted by other communities. The space (genotype) is exceptionally steady and has more grounded linkage, the shape-form (phenotype) is very consistent and has medium linkage, and the style may alter and has weaker linkage (Khamdevi, 2019a, 2019b, 2020a, and 2020b).

The Luhak Agam house is utilized the premise for comparison in analyzing the houses Rokan, see Table 2. The research locations in Rokan Hulu are as follows (see Figu re 2): Ujung Batu, Lubuk Bendahara, Rokan IV, Cipang Kiri Hilir, and Cipang Kiri Hulu.

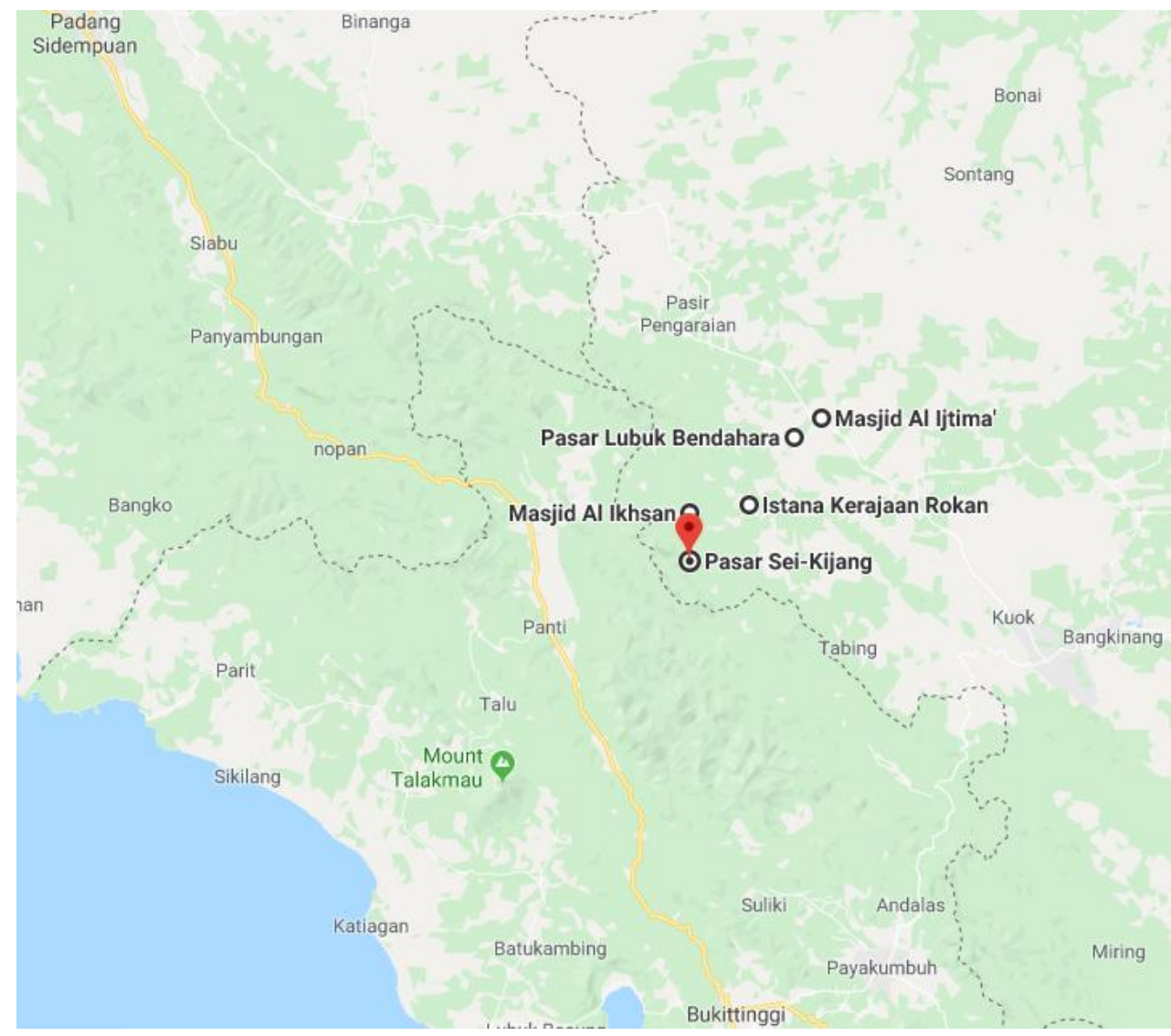

Figure 2. Research Location in Rokan Hulu (right)

Source: Google Maps, 2020 


\section{RESULTS AND DISCUSSION}

\section{A. Ujung Batu, Lubuk Bendahara, Rokan IV (a)}

The Rumah Godangs in Ujung Batu, Lubuk Bendahara, and Rokan IV (a), which we will discussed in this section, have same characteristics. When we entered the house we found a living room (Tongah). After that we would find the wood walled bedrooms (Bilik). At the back there is also a hallway leading to the door and stairs. These houses tend to follow the Rokan River stream and sometimes seem to follow the Qibla direction.

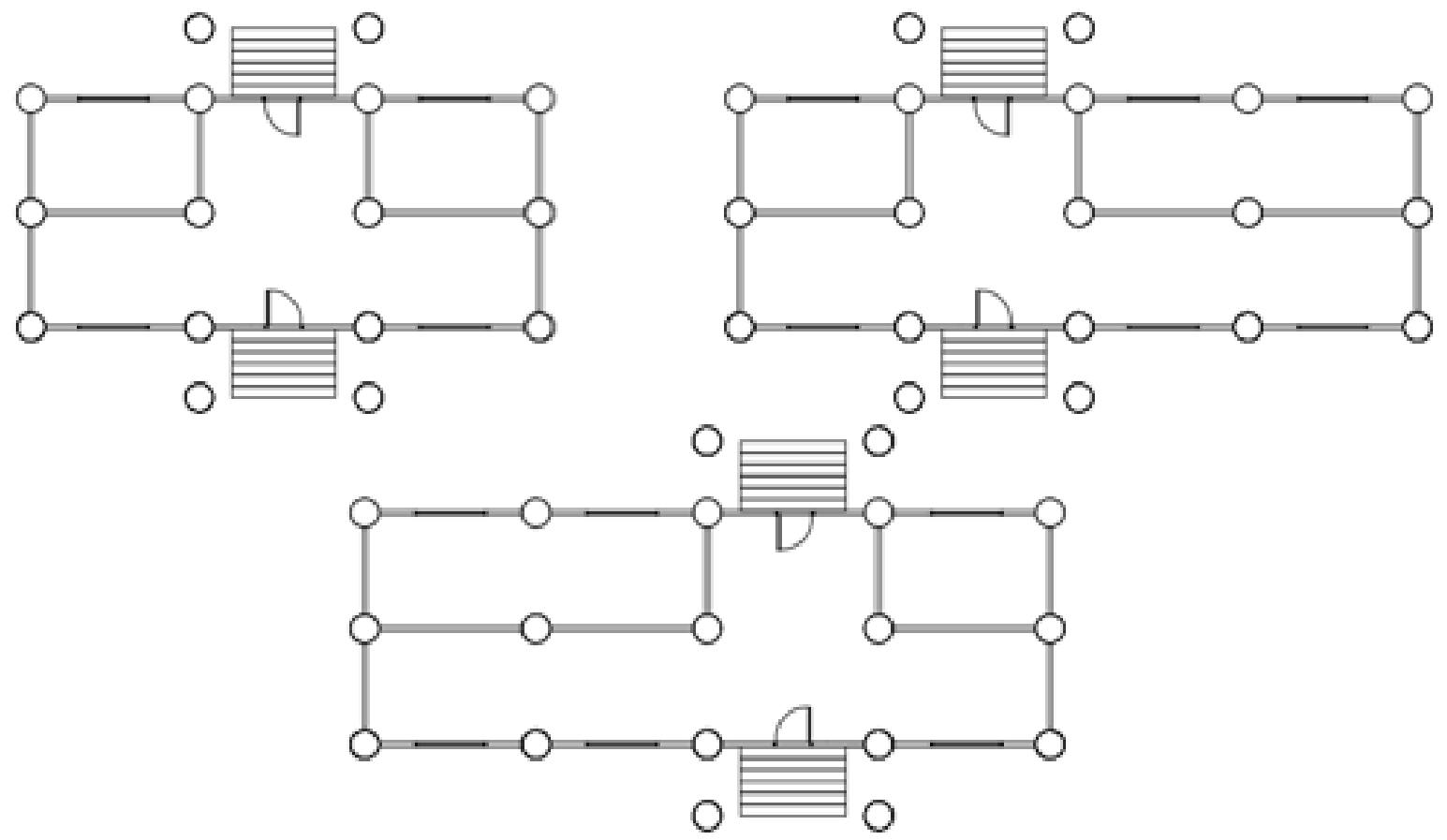

Figure 3. The Floorplan in Ujung Batu, in Lubuk Bendahara, and in Rokan IV (a) Source: Khamdevi, 2017-2020

These Rumah Godangs are stilt houses. The rooms extended to the side that made the house shape a transversal rectangular. The gable roof is covered with a zinc roof, which was previously covered with thatched roof. The building used wood as the main building material. The bedrooms are bordered by wooden walls to create privacy.
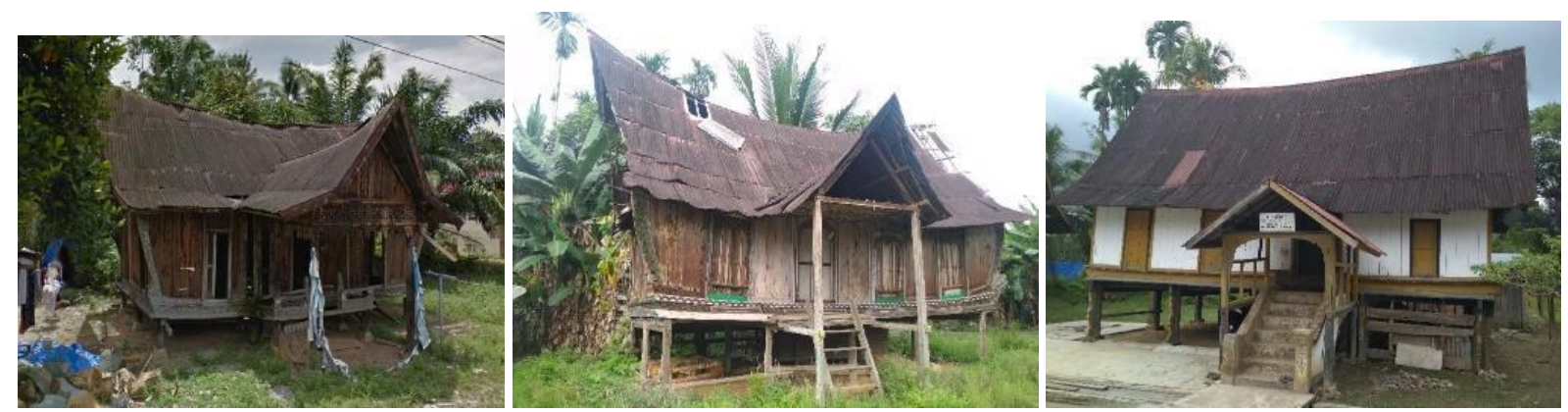

Figure 4. The houses in Ujung Batu, in Lubuk Bendahara, and in Rokan IV (a) Source: Khamdevi, 2017-2020 
The shape of the roof is known as the Lipek Kajang style (boat roof with low ridge) rather than Lipek Pandan (high ridge), where the ridge is slightly curved, not as steep as Rumah Gadang roof. At the top of the ridge there is no decoration. At first glance, the shape of this roof reminded us of the shape of the roof style in Luhak Tanah Datar. The pedestal foundation is made by stone. The section shape of the columns are octagonal. The central post behind the right of the door is called the Tiang Tuo, which was the first post to be built and sacred. The openings are front windows, front doors, and back doors. The stairs had an odd number of steps, around five to seven steps. There are kaluk pakis, pucuk rebung, and itik pulang petang ornaments at the foot of the the walls.

\section{B. Rokan IV b dan c, dan Cipang Kiri Hilir}

The Rokan IV (b) and (c), and Cipang Kiri Hilir houses have comparable characteristics. From the front of the house, we entered a small veranda (Surambi). After that, we would find a living room (Tongah) and sleeping rooms at the back (Bilik). Especially for Rokan IV (b), on the right and left there is an Anjung as a space for traditional leaders.
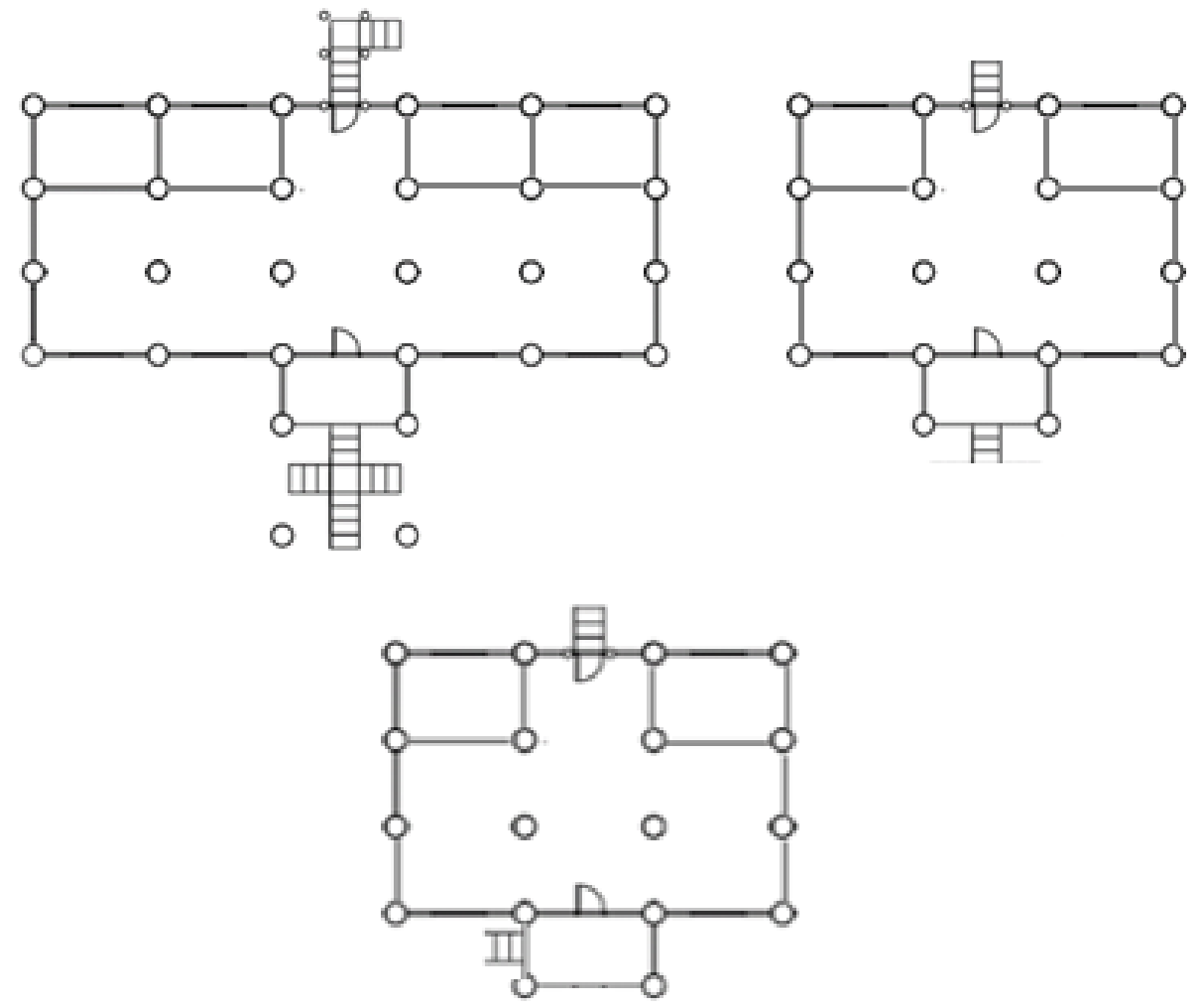

Figure 5. The Floorplan in Rokan IV (b) and (c), and in Cipang Kiri Hilir Source: Khamdevi, 2017-2020

These stilt houses had rooms that extended to the side that created a transversal rectangular shape. The roof has two levels, the roof below is in the form of a hip type, while the upper roof is gable type. The roofs are covered with a zinc roof, which was formerly made by thatched roof. Wood are the main building material. To create privacy, the wood walls bordered the bedrooms. 


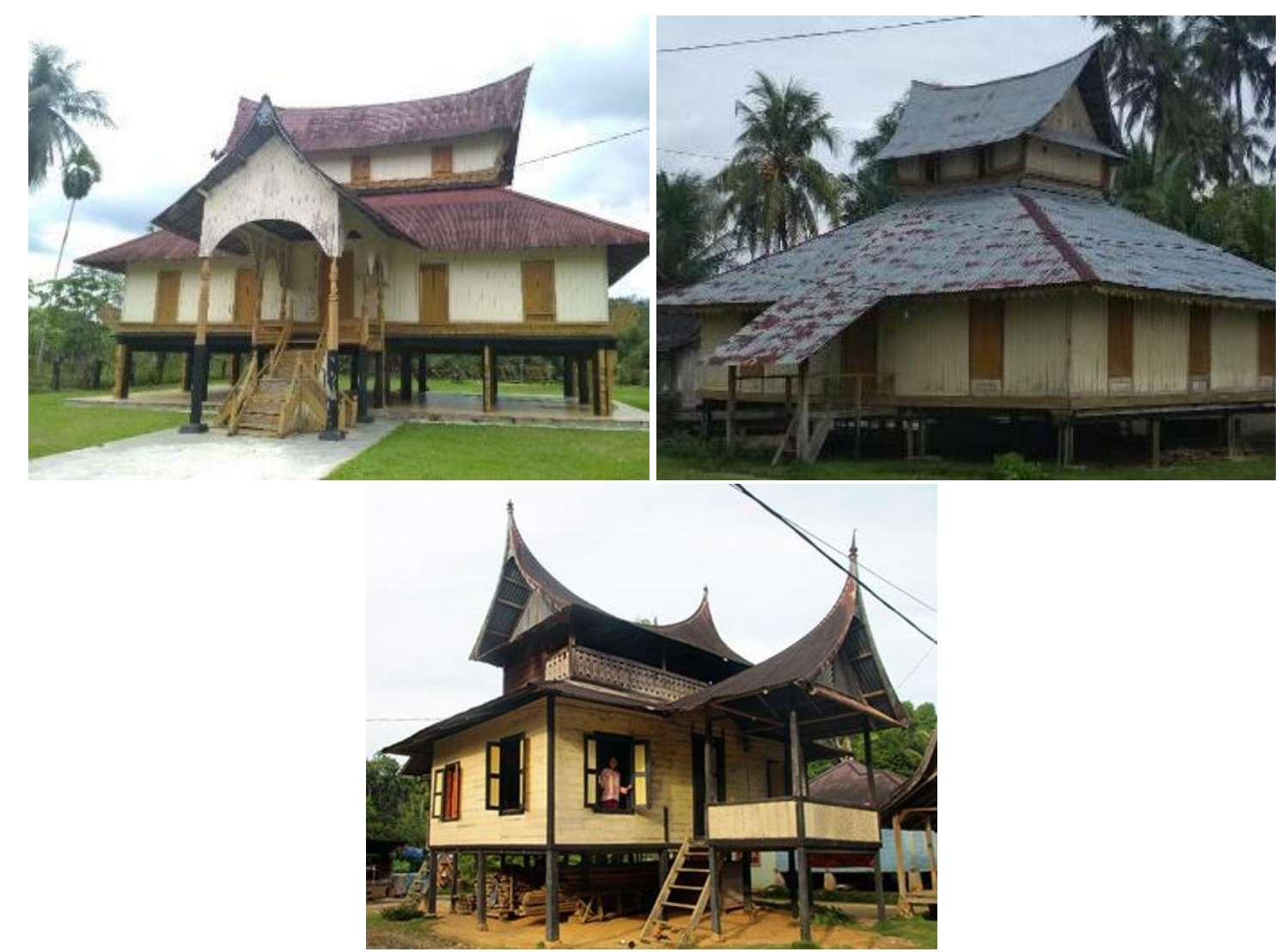

Figure 6. The houses in Rokan IV (b) and (c), and in Cipang Kiri Hilir Source: Khamdevi, 2017-2020

They have exceptionally comparable to Luhak Agam house form and shape. Based on interview, that former Rokan IV Palace (Rokan IV (b)) had a steep curved roof ridge (Lipek Pandan and Surambi Papek) and had Gonjong decorations at two ends of the ridge. They moreover specified that the Riau Government has renovated it and put new decoration patches with Selembayung; carved ornaments resembling buffalo horns. The columns stood on the stone pedestal foundations. The columns had an octagonal section shape. The Tiang Tuo as central post stood behind the right of the door. There are windows on each side of the building and doors at the front and back of the building. The stairs had an odd number of steps, approximately five to eleven steps. The main ornaments are kaluk pakis, pucuk rebung, and itik pulang petang at the foot of the walls.

\section{Additions: Rokan IV d dan Cipang Kiri Hulu}

The Rokan IV (d) house and the Cipang Kiri Hulu house are exceptionally comparable characteristics to the Rumah Gadang in West Sumatra. The house of Cipang Kiri Hulu is more comparative to the Rumah Gadang Luhak Agam (Lipek Pandan and Bapaserek or Surambi Papek), whereas the house of Rokan IV d is more comparative to the Rumah Gadang Luhak Tanah Datar (Lipek Pandan and Gajah Maharam). In terms of space, shape-form and style, they are very similar to Rumah Gadang in Agam. 


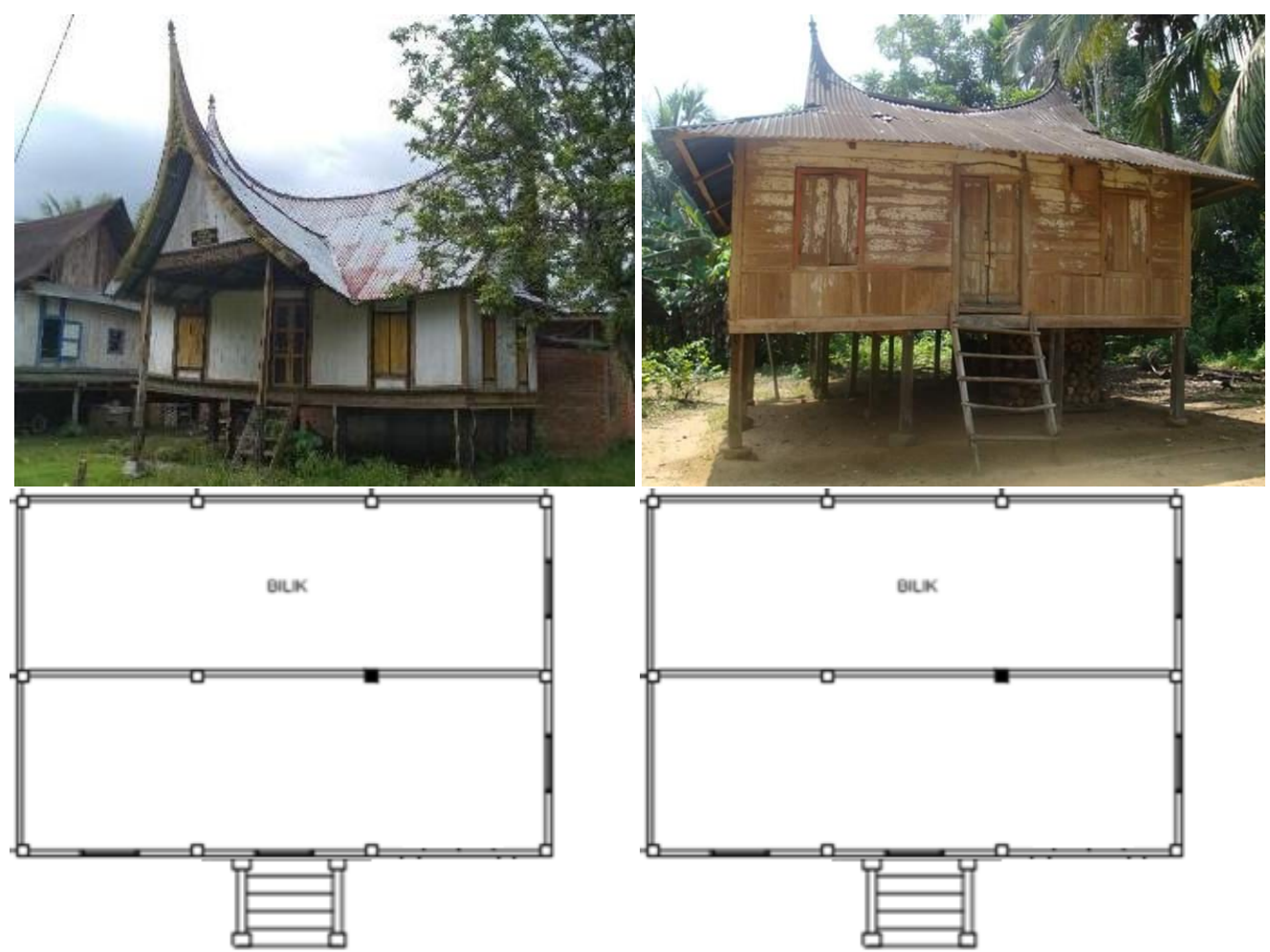

Figure 7. The House and its Floor Plan in Rokan IV (d) and in Cipang Kiri Hulu Source: Khamdevi, 2017-2020

\section{The Architectural Characteristics Linkage between Luhak Agam and Rokan Hulu}

As general, the characteristics between them have stronger linkage (see Table 4). The difference is only found on their roof ridge height. In Ujung Batu, Lubuk Bendahara, and Rokan IV (a), they used Lipek Kajang roof which is one type of common Malay roof located in the Downstream (Hilir) and the Coast (Pesisir) that has low ridge height. Others are more dominant using the other common Malay roof type - the Lipek Pandan - which is usually used in the upstream (Hulu) or inland (Pedalaman) - and also using the Agam roof style (Surambi Papek or Bapaserek) that has high ridge height. With the exception of the house of Rokan IV (d) that used Luhak Tanah Datar roof (Gajah Maharam).

Table 3. The Architectural Characteristics Linkage between Luhak Agam and Rokan Hulu

\begin{tabular}{|c|c|c|c|c|c|}
\hline $\begin{array}{l}\text { Architectural } \\
\text { Characteristics }\end{array}$ & & $\begin{array}{l}\text { Ujung Batu, } \\
\text { Lubuk } \\
\text { Bendahara } \\
\text { \& Rokan IV } \\
\text { (a) }\end{array}$ & $\begin{array}{c}\text { Rokan IV } \\
\text { (b) dan (c), } \\
\text { dan Cipang } \\
\text { Kiri Hilir }\end{array}$ & $\begin{array}{l}\text { Rokan IV } \\
\text { (d) }\end{array}$ & $\begin{array}{c}\text { Cipang Kiri } \\
\text { Hulu }\end{array}$ \\
\hline \multirow[t]{3}{*}{ Space } & Space & $\checkmark$ & $\checkmark$ & $\checkmark$ & $\checkmark$ \\
\hline & $\begin{array}{l}\text { Pattern } \\
\text { Orientation }\end{array}$ & $\checkmark$ & $\checkmark$ & $\checkmark$ & $\checkmark$ \\
\hline & Hierarchy & $\checkmark$ & $\checkmark$ & $\checkmark$ & $\checkmark$ \\
\hline \multirow[t]{3}{*}{ Shape-Form } & $\begin{array}{l}\text { Physical } \\
\text { form }\end{array}$ & $\checkmark$ & $\checkmark$ & $\checkmark$ & $\checkmark$ \\
\hline & $\begin{array}{l}\text { Materials } \\
\text { Space }\end{array}$ & $\checkmark$ & $\checkmark$ & $\checkmark$ & $\checkmark$ \\
\hline & Barrier & $\checkmark$ & $\checkmark$ & $\checkmark$ & $\checkmark$ \\
\hline
\end{tabular}


Style $\quad$ Roof

\author{
Column \\ Openings \\ Stairs
}

Source: Khamdevi, 2017-2020

\title{
CONCLUSION
}

Rumah Gadang in Agam and Rumah Godang in Rokan have a very strong relationship. It can be concluded that they both have the same cultural traits of Malayic-speaking culture, even very close. The principle of the space arrangement, the shape-form of the transversal rectangular body and the roof type, the style of the roof and ornaments are strongly consistent. The only difference is their roof ridge height, where one used Lipat Pandan or Hilir-Pesisir type, while the other used Lipat Kajang or Hulu type. However, both are common Malay roof types.

The results of this study are expected to provide ideas and contribute to the preparation of historical narratives of pre-Indonesian architecture which have not yet been available. This opens up opportunities for a wider range of similar research and encourages diversity of reserach.

\section{REFERENCES}

Anderbeck, Karl Ronald (2007). "An initial reconstruction of Proto-Lampungic: phonology and basic vocabulary". Studies in Philippine Languages and Cultures. SIL International. 16: 41-165.

Boestami dkk. (1979). Arsitektur Tradisional Minangkabau: Rumah Gadang. Padang: Kantor Wilayah Departemen P dan K Provinsi Sumatera Barat.

Coedes G. (2014). Kedatuan Sriwijaya. Depok: Komunitas Bambu.

Couto, N. (2008). Budaya Visual Seni Tradisi Minangkabau. Padang: UNP Press.

Gero J. S. and Ding L. (2001). Exploring Style Emergence in Architectural Designs. Environment and Planning B: Urban Analytics and City Science. Vol. 28 No. 5.

Guney (2007). Type and Typology in Architectural Discourse. Bau FBE Dergisi. Vol. 9 No. 1.

Habraken, N. John (1988). "Type as Social Agreement". Asian Congress of Architect, Korea.

Khamdevi, Muhammar (2019a). The Architectural Characteristics Linkage of Batang Kuantan's Rumah Godang with Tanah Datar's Rumah Gadang. Langkau Betang: Jurnal Arsitektur 6 (2): 111-120.

Khamdevi, Muhammar (2019b). The Linkage of Kampar's Rumah Lontiok with Limapuluh Koto's Rumah Gadang. Nature: National Academic Journal of Architecture 6 (2): 103-112. https://doi.org/10.24252/nature.v6i2a1.

Khamdevi, Muhammar (2020a). Revisiting the Minangkabau Traditional House in the Central Area of Sumatra: The Case of Limapuluh Koto and Bangkinang. In Proceeding Reframing the Vernacular: Politics, Semiotics, and Representation: 239-250.

Khamdevi, Muhammar (2020b). Revisiting the Traditional House in the Central Area of Sumatra: The Case of Dharmasraya in West Sumatra and Batang Kuantan in Riau. In Book Chapter IOP Conference Series: Earth and Environmental Science 452: 012008.

Kozok, U. (2006). Kitab Undang-Undang Tanjung Tanah: Naskah Melayu yang Tertua. Jakarta: Yayasan Obor Indonesia.

Nothofer, Bernd (1985). "The subgrouping of Javo-Sumatra Hesion: A reconsideration". Bijdragen tot de Taal-, Land- en Volkenkunde. Brill. 141 (2/3): 288-302.

Schefold, R. et al. (2008). Indonesian House, Volume 2: Survey of Vernacular Architecture in Western Indonesia. Leiden: KITLV Press.

Syamsidar, B.A. (1991). Arsitektur Tradisional Daerah Sumatra Barat. Jakarta: Departemen Pendidikan dan Kebudayaan.

Tumonggor, M. et al (2013). "The Indonesian archipelago: an ancient genetic highway linking Asia and the Pacific". J Hum Genet, 58, p. 165-173. 